\title{
AN ANALYSIS OF CODE-MIXING USED BY BOY WILLIAM ON VLOG \#DIBALIKPINTU
}

\author{
Dwi Handayani' ${ }^{1}$ Ricky Eka Sanjaya ${ }^{2}$ \\ ${ }^{1,2}$ Universitas Indraprasta PGRI \\ Jl.Nangka Raya No.58 C Tanjung Barat, Jakarta Selatan 12530, Indonesia
}

Corresponding Author(S): handayanidwi.unindra@gmail.com

\begin{abstract}
:
The research aims to describe and to analyze the forms of code-mixing used by Boy William on Vlog \#Dibalikpintu. This study was a descriptive qualitative method and human research is the main instrument of this study. In collecting the data, this study utilized observation and documentation methods. This study employed content analysis which focused on analyzing the forms of code-mixing which were defined by Suwito (1983). The result of this study: In the word form, there are 19 data found, (15 nouns, 2 verbs, 1 adjective, 1 question word). In the phrase form, there are 19 data found, (17 noun phrases, 2 adjective phrases). In the baster form, there are 5 data found, (1 noun as a form of gerund suffixation, 3 noun suffixation, 1 verb suffixation). In the word reduplication form, there are 2 data found, (1 noun, 1 compound noun). In the idiom form, there are 2 data found, (1 formal idiom, 1 informal idiom). In the clause form, there are 25 data found, ( 8 noun clauses, 14 verb clauses, 3 adjective clauses).
\end{abstract}

Keywords:

Sociolinguistics, Code-Mixing, Vlog.

\section{INTRODUCTION}

Human is social beings who are required to socialize with others as an essential need. They need to socialize by interaction and communication with social groups. In interacting and communicating, human needs a language as a media. Language has a main function as a tool of communication between human. Through language, a person can understand what is conveyed and heard in accordance with the existing language context. Language context is the situation and conditions that surround a conversation. In language, a person must pay attention to the context of the language in order to understand a sentence or utterance correctly.

Context of the language greatly influences the fluency of the communication system because the differences in language context can cause language meanings itself. The relationship between language and the context of society and culture is studied in 
sociolinguistics. According to Trudgill (2000:21) "Sociolinguistics is that part of linguistics which is concerned with language as a social and cultural phenomenon. It investigates the field of language society and also the attitudes to forms of language." On the other hand, sociolinguistics provides guidelines for communicating by showing what language, language variety, or language style that should be used when talking to certain people.

Language variation is the variety or difference in language use. The variety of languages is related to the social diversity of the speakers and the diversity of the functions of the language itself. The diversity of languages will increase if the language is used by many speakers and is located in a large area such as in Indonesia. The occurrence of language diversity is not only caused by the speakers who are not homogeneous, but also because of the diversity of social interaction activities they carry out. Language variation can be seen through various aspects, including social status, gender of the speaker, time, place and field of language use, as well as the situation of language formalities and so on.

With the large variety of languages that exist, it will allow language contact which rise to the language phenomenon, namely bilingualism and multilingualism. According to Bhatia (2004) "The terms bilingualism and multilingualism have come to be used, respectively, to refer to the knowledge and use of two languages and the knowledge and use of three or more languages."

There are several factors that make a person become bilingual or multilingual, one example is migration, which is the movement of people that causes multiple languages. In addition, the educational factor also motivates someone to become bilingual or multilingual, such as at school, students are taught a foreign language. Indonesian people are generally bilingual and multilingual because they have the ability to use two or more languages, namely mother tongue, national and foreign languages. The use of more than one language is the background for the emergence of linguistic phenomena, namely interference, integration, code-switching and code-mixing.

Multilingual communities are accustomed to changing languages from one language to another in their interaction. Interaction involves language diversity will result in the choice of language or language mixing to be used. A language mixing event is referred to as a code-mixing. According to Nababan (1993:32) "Code mixing is a mixing of two codes or languages usually without a change of topic." Code-mixing can occur in the absence of situations that require mixing of languages, but it can also be caused by several factors such as: environment, prestige, social class, the habit of the speakers, and the informality of the situation.

Furthermore, Muysken (2000:1) stated that "Code-mixing refers to all cases where lexical items and grammatical features from two languages appear in one sentence." Meanwhile specific to form of code-mixing, it can be divided into six forms Suwito (1983). Those are words, phrases, baster, word reduplication, idioms, and clauses.

Table 1 Forms of Code-Mixing (Suwito, 1983)

\begin{tabular}{ll}
\hline \multicolumn{1}{c}{ Forms of Code-Mixing } & Description \\
\hline Words & Word is language unit that stands on its own, it consists of free morphemes and bound \\
& morphemes. Words do not always constitute the smallest meaningful units in a \\
& language. Instead, words are sometimes constructed of smaller parts. These parts are
\end{tabular}




\begin{tabular}{ll}
\hline \multirow{3}{*}{ Phrases } & called morphemes. \\
& Phrase is a group of two or more related words that is not certain both as subject and a \\
predicate. & Baster is a combination of word pieces, the combination of Indonesian word and the \\
Baster & English word, usually in the shape of suffix and prefix. \\
& Word reduplication is the repetition of some parts of the base (which maybe the entire \\
Word Reduplication & base) more than one word. \\
Idioms & each its component parts. The idiom is a phrase or sentence whose meaning is not clear \\
& from the meaning of its individual's words and which must be learnt as a whole unit. \\
& Clause is a group of words having a subject and predicate some clauses are \\
independents, so they can stand themselves as sentences or may appear within \\
Clauses
\end{tabular}

Commonly, on vlog, code-mixing have easily to be found. Conversation in each vlog has the ability to be a good example of code-mixing because the fact that it is shows various the forms of code-mixing which occured depends on some reasons such as; talking about a particular topic, quoting somebody else, being emphatic about something, interjections, repetition used for clarification, the intention of clarifying the speech contents for the interlocutor, and expressing group identity. This research only focused on the analysis the forms of code-mixing. The research was addressed to answer the following research question: how to analyze the forms of code-mixing used by Boy William on Vlog \#Dibalikpintu

\section{METHOD}

The purpose of this research was to analyze the forms of code-mixing used by Boy William on Vlog \#Dibalikpintu. The vlogs which analyzed have 10 - 15 minutes duration. There are five vlogs; KEDIAMAN RAJA FILM INDONESIA! Beginilah Dibalik Layar! Manoj Punjabi \#Dibalikpintu, ADA LAPANGAN GOLF DAN MESJID PRIBADI DI HALAMAN RUMAH! Ovi Dian ngundang Boy! \#Dibalikpintu, INTIP RUMAH LUCU DI LANGIT! MILIK OWNER AXIOO \#Dibalikpintu, VALENCIA TANOESOEDIBJO: KEHIDUPAN ANAK KONGLOMERAT BIKIN MELONGO! \#Dibalikpintu, INDONESIAN IDOL TERBONGKAR SAMPE DANIEL MANANTA KELUAR! TERNYATA... \#Dibalikpintu.

The researcher use a qualitative research framework in content analysis method. The object of the research was the utterance. According to it, there were 74 utterances that can be categorized as code-mixing performed by Boy William. The utterances then were analyzed, categories and grouped into forms of code-mixing by Suwito (1983). The findings were presented using tables and textual description.

\section{RESULTS AND DISCUSSION}

From 74 utterances of Boy William on vlog \#Dibalikpintu, they can be classified into forms of code-mixing. There were 19 utterance in the form of words, 19 utterances in the form of phrases, 5 utterances in the form of baster, 2 utterances in the form of word reduplication, 2 utterances in the form of idioms, and 25 utterances in the form of clauses.

\section{Words}

Code-mixing in the form of words are found when Boy William tried to ask questions, to tell something in English but also familiar in Indonesian and to describe something when he didn't find a suitable word in Indonesian. From 19 utterances that are classified as words, it consists of 15 nouns, 2 verbs, 1 adjective, 1 question word. Boy William used 
code-mixing in the form of words also because he tried to express a group of identity and talk about a particular topic.

For instances, Boy William uttered “Jadi ini lapangan golf lo ada berapa hole?". In this utterance, Boy William asked Ovi Dian as the owner of a golf course in her backyard. He performed code-mixing by saying hole that means the hole in the ground on the putting green as the object of the game. Hole identified as a form of word and classified as a noun.

The utterance "Orang gue nungguin elu meeting." performed by Boy William when he waited for Valencia Tanoesoedibjo in her office. He used the word meeting because that is English but commonly used, also more prestigious and has direct meaning to something that is an assembly of people, especially the members of a society or committee, for discussion or entertainment. Meeting identified as a form word and classified as a noun (gerund).

Table 2 Code-Mixing in the Form of Words

\begin{tabular}{lcc}
\hline Utterance & Code-Mixing & Classification \\
\hline "Jadi ini lapangan golf lo ada & Hole & Noun \\
berapa hole?" & & Noun \\
“...cowok itu harus datang dari & Privilege & \\
keluarga yang privilege juga & & Noun \\
"Kenapa Ci Fen suka banget & Photography & Noun \\
sama photography?” & Meeting & Adjective \\
meeting." gue nungguin elu & Affordable & \\
"dan yang paling penting & & \\
\hline
\end{tabular}

\section{Phrases}

There are 19 utterances that are classified as phrases, it consist 17 noun phrase and 2 adjective phrase. Code-mixing in the form of phrases occurred mostly when Boy William tried to be empathic to his interlocutor, to tell the term, and also asking question that it consider more polite if it asked in English instead of in Indonesian.

The utterance "Pak Manoj, jadi gapapa nih kita ntar ngeliat-ngeliat behind the life of MD Production?". In this case, Boy William performed code-mixing which intended to ask and gain information from Manoj Punjabi. The form of code-mixing above is Phrase, specifically Noun Phrase. Classification: Behind is an adverb, the is determiner, life is a noun, of is a preposition, MD Production is a proper name.

Another code-mixing found in the utterance "Apa gambar ini.......tentang your sadness?" In this case, Boy William tried to be empathic when he asked and the usage of English here was considered way more polite. It is a Noun Phrase. Classification: Your is a possessive pronoun, sadness is a noun which is derived from sad (adjective) and -ness (suffix).

Table 2 Code-Mixing in the Form of Phrases

\begin{tabular}{lcc}
\hline \multicolumn{1}{c}{ Utterance } & Code-Mixing & Classification \\
\hline "Pak Manoj, jadi gapapa nih kita & behind the & Noun Phrase \\
ntar ngeliat-ngeliat behind the & life of MD Production & Noun Phrase \\
life of MD Production?" & to get these things as a producer, & Noun Phrase
\end{tabular}




\begin{tabular}{lcc}
\hline "Dari lima karyawan, dan & your favorite artist & Adjective Phrase \\
sekarang a building." & & Noun Phrase \\
"Pak Manoj kalau bilang aku & like your family business & \\
your favorite artist." & & \\
"Elu gak disuruh nerusin like & &
\end{tabular}

\section{Baster}

Code-mixing in the form of baster are found when Boy William combined English and Indonesian word usually in the shape of suffix and prefix. In this research, baster form mostly appeared with suffixation. There are 5 utterances, it consists of 1 noun as a form of gerund suffixation, 3 noun suffixation, 1 verb suffixation.

For instances, the utterance "Mau syutingnya bagus tapi editing-nya kurang...ancur." In this case, Boy William talked about film editing. He used editing because it is English word that is commonly used in Indonesia. Editing is code-mixing in baster form. Editing is English word which is classified as a noun in gerund form, and -nya as the addition of a suffix.

The utterance "rumah lu tuh design-nya apa?" is performed by Boy William to ask for information related Ovi Dian's house. He combined English and Indonesian word to talk about a particular topic. Design is code-mixing in baster form which is classified as a noun, and -nya as the addition of a suffix.

Table 3 Code-Mixing in the Form of Baster

\begin{tabular}{lcc}
\hline Utterance & Code-Mixing & Classification \\
\hline "Mau syutingnya bagus tapi & editing-nya & Gerund suffixation \\
editing-nya kurang...ancur." & design-nya & Noun suffixation \\
"rumah lu tuh design-nya apa?" & cream-nya & Noun suffixation \\
"Jadi day cream-nya kita pake & cream-nya & Noun suffixation \\
sebelum berangkat kerja." & kick-nya & Verb suffixation \\
"dan mereka juga ada night & & \\
\hline
\end{tabular}

\section{Word Reduplication}

There are 2 utterances that are classified as word reduplication, it consist of 1 noun phrase and 1 compound noun. Code-mixing in the form of word reduplication occurred mostly when Boy William tried to repeat the same English word to show the amount of things and also uttered because of habit.

The utterance "buat kalian yang mau dapet gift-gift yang keren." performed by Boy William in the endorsement section on his vlog. Code-mixing in the form of word reduplication occurred because he said the word gift two times to tell his viewers if there are many gifts that they are able to get. Gift is classified as a noun.

Word reduplication is also found in the utterance "Jadi gue bisa ngitung berapa kali si boy high-five high-five an sama orang.". In this case, Boy William told the experience how his viewers paid attention and counted how many times he did high-five with his interlocutors. This code-mixing describes the amount as well. High-five is classified as a compound noun. 
Table 4 Code-Mixing in the Form of Word Reduplication

\begin{tabular}{lcc}
\hline Utterance & Code-Mixing & Classification \\
\hline "buat kalian yang mau dapet gift- & gift-gift & Noun \\
gift yang keren." & high-five high-five & Compound noun \\
"Jadi gue bisa ngitung berapa & & \\
kali si boy high-five high-five an & & \\
\hline
\end{tabular}

\section{Idioms}

Code-mixing in the form of idioms occurred in 2 utterances. It consists of 1 formal idiom and 1 informal idiom. The idiom is a phrase or sentence whose meaning is not clear from the meaning of its individual's words and which must be learnt as a whole unit.

For instances, the utterance "Tapi gue masih belajar maaan, like I'm a shit ass di sini bro." performed by Boy William when he talked about a particular topic with his interlocutor. Shit ass means inconsiderate or rude person. But, based on the context from the whole conversation, shit ass in this utterance means when someone is considered a know-it-all person whereas he is just a newbie. Shit ass is classified as an informal idiom.

The utterance "Semua produknya aman banget by the way." is also considered as codemixing. It occurred as additional information when Boy William gave the details about the endorsement product on his vlog. By the way is classified as a formal idiom and usually used to introduce a new subject to be considered or to give further information.

Table 5 Code-Mixing in the Form of Idioms

\begin{tabular}{lcc}
\hline Utterance & Code-Mixing & Classification \\
\hline $\begin{array}{l}\text { "Tapi gue masih belajar maaan, } \\
\text { like I'm a shit ass di sini bro." }\end{array}$ & shit ass & Informal idiom \\
"Semua produknya aman banget & by the way & Formal idiom \\
by the way." & & \\
\hline
\end{tabular}

\section{Clauses}

There are 25 utterances that are classified as clauses, it consists of 8 noun clauses, 14 verb clauses, 3 adjective clauses. It occurred when Boy William tried to ask questions, to give compliments, and to describe something. From all forms of code-mixing which was performed by Boy William, clause form is the most used form in his utterances.

The utterance "Pokoknya yaudah I'll see you there." is considered as code-mixing in the form of a clause because it shows a complete statement. It is specifically as verb clause Classification: I is the first singular personal pronoun, will is an auxiliary verb, see is a verb (in present form), you is the second singular personal pronoun, there is an adverb of place.

Another code-mixing found in the utterance "Buat kalian yang mau ngecilin pori-pori this is really good." The form of code-mixing above is Clause, specifically Adjective Clause. Classification: This is a demonstrative pronoun (in singular form), is is a to be (in present form), really is an adverb of manner, good is an adjective.

Table 6 Code-Mixing in the Form of Clauses

\begin{tabular}{lcc}
\hline Utterance & Code-Mixing & Classification \\
\hline $\begin{array}{l}\text { "Pokoknya yaudah I'll see you } \\
\text { there." }\end{array}$ & I'll see you there & Verb clause
\end{tabular}




\begin{tabular}{lcc}
\hline "Buat kalian yang mau ngecilin & this is really good & Adjective clause \\
pori-pori this is really good." & we gotta care ourselves & Verb clause \\
"Meskipun kita cowok we gotta & & Verb clause \\
care ourselves." & & \\
"Lu emang you interested in the & you interested in the entertainment business & Noun clause \\
entertainment business?" & they have subtitles & \\
"Jadi kalo orang Thailand nonton & &
\end{tabular}

\section{CONCLUSION}

Based on the analysis of 74 data of code-mixing, the researcher found some types that showed the forms of code-mixing and its reason. A variety of utterances used codemixing in the forms of words, phrases, baster, word reduplication, idioms, and clauses. From the study above, it can be found 19 data in the word form (15 nouns, 2 verbs, 1 adjective, 1 question word). In the phrase form, there are 19 data found, (17 noun phrases, 2 adjective phrases). In the baster form, there are 5 data found, ( 1 noun as a form of gerund suffixation, 3 noun suffixation, 1 verb suffixation). In the word reduplication form, there are 2 data found, ( 1 noun, 1 compound noun). In the idiom form, there are 2 data found, ( 1 formal idiom, 1 informal idiom). In the clause form, there are 25 data found, ( 8 noun clauses, 14 verb clauses, 3 adjective clauses). It shows code-mixing in Boy William's utterances mostly used to perform his complete statement in the form of clauses.

\section{REFERENCE}

Bhatia, T. K. (2004). The Handbook of Bilingualism and Multilingualism. United Kingdom: Blackwell Publishing.

Muysken, P. (2000). Bilingual Speech: A Typology of Code-Mixing. United Kingdom: Cambridge University Press.

Nababan. (1993). Sosiolinguistik Suatu Pengantar. Jakarta: Gramedia Pustaka Utama.

Suwito. (1983). Pengantar Awal Sosiolinguistik: Teori dan Problema. Surakarta: Fakultas Sastra Universitas Sebelas Maret.

Trudgill, P. (2000). Sociolinguistics: An Introduction to Language and Society. London: Penguin Group. 